УДК 81'32

https://doi.org/10.31548/philolog2020.01.114

\title{
COMMUNICATIVE STRATEGIES IN CROSS-CULTURAL BUSINESS ENVIRONMENT
}

\author{
O. I. CHAIKA, PhD in Philology, Associate Professor, \\ National University of Life and Environmental Sciences of Ukraine \\ E-mail: oxana.chaika@yahoo.es \\ https://orcid.org/0000-0002-4317-9456
}

\begin{abstract}
The present paper looks at a set of communicative strategies employed in the international business by English-speaking business people in general, and auditors and accountants, in particular. The work aims at the relevance of cross-cultural communication and the generally accepted classification of communicative strategies in English. Thus, to meet the objectives, a concept of intercultural communication comes to description to be followed by the stages of the message delivery. These relate to (i) encoding of the message, (ii) choice of a medium / media to transmit a relevant message, and (iii) decoding of the message. As respects intercultural communication, the article speaks of relevance in understanding the particular backgrounds, which the communicants in the international business environment may not ignore. English-speaking business people may make great experts in their professional domain of activities, however, that may not guarantee they would never face a wide range of challenges, which would arise in the course of communication between the business people - colleagues, peers, business partners or just business contacts from different countries. One of the reasons for some difficulty in interaction can link to their belonging to different cultural backgrounds, for example, religious, social, ethnic, educational, etc. It is important to note that the contemporary progress with digitization and globalization influences ways of thinking, beliefs and values. The ethnic identity borders dissolve in the global processes of integration. Open borders and more opportunities to travel and discover the world may not, but impact the personality, their perception and interpretation of the world within and between cultural environments. Therefore, the topicality of the work highlights the need in the unified approach to simplified interaction despite the borders and time zones and moves the needle with the classification of seven communicative strategies business people may employ for work when travelling and speaking English. To help better understand each strategy, the explanations are furnished with the English examples for a certain communicative context.
\end{abstract}

Key words: Intercultural communication, cross-cultural communication, encoding / decoding of the message, encoder / decoder, communicative strategy, nomination, restriction, turn-taking, topic control, topic shifting, repair, termination.

Introduction. Communication is an art. Communication is often misinterpreted and confused with a conversation or a talk, or a message etc. The present paper establishes that the difference between a conversation and communication is crucial. That is to say, a conversation may presuppose that two or more people express their opinions or share some information. However, it may not guarantee that what is said by the speaker is always understood that way by the listener. Similarly, we may look at a dialogue. When two people talk to each other, there is no certainty they may be successful in their interaction. Each may try hard to deliver his/her message and focus on its presentation. As regards the other, s/he may act in the same way. That is why when we deal with a number of people engaged in communication and focused on their individual messages, the contents of such messages and the form of relevant expression, correspondingly, we consider the context as well. Even in such a

(C) O. I. Chaika

«International journal of philology» | «Міжнародний філологічний часопис» Vol. 11, № 1, 2020 
circumstance that may not be enough. The next step is intercultural communication, in which people belong to different backgrounds and speak different languages. It just happens so that in the world of business everyone comes to speak English. Following Su Kei (2015), "communication is no longer confined solely to a community and nationwide level but also on an international scale" [7]. Further, the author states "intercultural communication is now more important than it ever was for enterprises. Yet the effective intercultural communication needed for the aforementioned success is difficult to achieve" [7]. Thus, the objective of the paper is to highlight the relevance of crosscultural communication in the business environment and describe a set of the communicative strategies in English, which business people may employ for efficient intercultural business relations. The methods applied are deduction and induction, and the descriptive method. With the said it may be possible to specify the need in appropriate communicative technology, as Giles and Ogay (2007) underline "Interactants use specific communication strategies (in particular, convergence and divergence) to signal their attitudes towards each other and their respective social groups" [3, 294].

\section{Intercultural Communication}

Intercultural communication, also known as cross-cultural communication, generally refers to cross-culture studies. Next, the term cross-cultural communication derives from the subject matter of the research, i.e. intercultural communication makes a field of study / discipline that focuses on communication across different cultures and/or societies, and/or communities as social groups, on the one hand. On the other, that is a discipline, which looks into the ways of culture embodiment, for example, what is the impact of culture on communication, how culture influences communication modes.

At the same time, intercultural communication as a field of study helps us see a variety of communication processes and a wide range of challenges that may arise in the course of communication between the people that belong to different cultural backgrounds. Further, such gaps in communication may appear not only between the people of different origin and speaking different languages. One may find it quite regular to hear within any social context, even a home or office environment made up of individuals from different backgrounds, in particular:

(i) Religious, e.g. a European woman married to an Arabic man,

(ii) Social, for example, a senior manager (from a well-to-do family) giving instructions to an employee that comes from the working class family,

(iii) Ethnic, for instance, a French Canadian making a dialogue with an English Canadian,

(iv) Educational, a scholar and a teenager from a vocational school having an argument.

The key objective of cross-cultural communication is to understand how people from different geographic regions, countries and cultures act, communicate and perceive and interpret the world around them.

Some scholars such as Wierzbicka (2018), Tiszczenko (2011), Chaika (Čajka) (2015) underline the importance of the study dedicated to how individuals encode messages and the ways such messages get interpreted $[4 ; 8 ; 1]$. It is believed that the three instances take relevance in crossculture commu-nication:

1) Encoding of a message;

2) Choice of a medium / media to transmit a relevant message;

3) Decoding of a message.

Encoding the message. The encoding of a message stands for the production of the message. In a broad sense, it is a system of coded meanings. Roughly speaking, the encoder / sender / speaker (but not always the speaker, as we will later speak about non-verbal forms and ways of communication) in order to create a set of coded meanings also needs to understand

(C) O. I. Chaika

«International journal of philology» | «Міжнародний філологічний часопис» Vol. 11, № 1, 2020 
how the recipient / listener can read and decode such a message. This sender / speaker will have to understand how the world is comprehensible to the recipient as part of the audience.

Choice of a medium / media. While encoding, the sender (encoder) applies various tools and techniques. It means that the encoder / sender / speaker chooses what medium best suits the goal to communicate the intended idea, on the one hand, and on the other, the encoder believes this medium will help the recipient / the decoder to understand / translate / decode the message.

At this point, it is necessary to distinguish between the symbols applicable to reach the goal. These may be as below:

(i) Verbal, and

(ii) Non-verbal.

When we speak about the verbal symbols, we mean words, algebraic or other signs, numbers, photos, pictures, other images, video etc. When we speak about non-verbal symbols in communication or cross-cultural communication, we refer to body language, mimes (facial expressions) and (hand) gestures, certain signals and actions. It is crucial to note that the way of encoding a message is partially driven by the purpose of the message.

Decoding of a message. Decoding of a message speaks of how the recipient / the listener / the decoder is able to catch the meaning, understand and interpret the message. It means that decoding of a message relates to interpretation and translation of coded information into a comprehensible form. The recipient / decoder tries to go back in the message generation and see the idea how it was born. The decoder starts attributing meanings to symbols received, which altogether enables him / her to interpret the message as a whole.

To sum it up, we may speak of communication rather than a conversation, talk or dialogue only when the message duly passes through all the stages of encoding, choice of right media for encoding the intended meanings, and decoding, i.e. the message is received and understood in the intended way.

Sadly, as it may seem, it is not always that communication is effective, especially in a context of different cultures and languages. There are a lot of situations in which the recipient of the message / the decoder fails to read the symbols well and s/he happens to understand a message in a completely different way from what the encoder was trying to convey. Here one may speak of socalled cultural misunderstanding. Experience of the encoder and decoder greatly influences the outcome. When dealing with communicative distortions in religious or social backgrounds, the communicants are yet to discover more ways of anticipating the comprehensiveness model. When looking at the linguistic side, deviations in encoding a message and/or distortions born with the decoder may arise from the non-native English-speaking background. In other words, such cultural misunderstanding goes with lack of linguistic experience or inability by both the encoder and the decoder find proper equivalence for symbols and ideas in the course of communication.

Broadly speaking, the above description links the research focus of cross-culture study and ethnolinguistics, or anthropological linguistics. Goddard and Wierzbicka (2018) in the chapter Minimal English and How It Can Add to Global English argue for "the great importance of cross-translatability in many contexts" and show with examples that "many taken-forgranted words and concepts of Anglo English are heavily culture-laden and hence untranslatable" $[4,16]$. Based on the stated, speaking English for business may be a challenge to non-native business people. Moreover, it may be getting more complicated when other factors of varied backgrounds move to the top.

However, Jacob Lauring (2011) in his work Intercultural Organizational Communication: The Social Organizing of Interaction in International Encounters argues that the above applies to international business communication [5]. The similar ideas favour the argument of the shared

(C) O. I. Chaika

«International journal of philology» | «Міжнародний філологічний часопис» Vol. 11, № 1, 2020 
international linguistic domain in a certain professional field of business activities, which presupposes understanding of technical terms by professionals and experts irrespective of their mother tongues.

To conclude, of fundamental value in intercultural communication proper is the process of interaction. Aside from language, intercultural communication focuses on the below:

(i) Social attributes,

(ii) Thought patterns, and

(iii)The cultures of different groups of people,

(iv) Attempts to understand the different cultures, to speak languages and get acquainted with the customs and traditions of people from various communities, societies, countries across the globe.

It is important to follow that the contemporary progress with digitization and globalization influences ways of thinking, beliefs and values. The ethnic identity, the ethnic identity borders get dissolved in the global processes of integration. Open borders and more opportunities to travel and discover the world may not, but impact the personality, their perception and interpretation of the world within and between cultural environments.

The study of cross-cultural communication requires intercultural understanding. It teaches to be tolerant about everything - sex, religion, social class, and politics, etc. It teaches to understand and value cultural differences. Language is one of significant, and in some instances, prominent cultural components that are associated with intercultural understanding.

To meet the need in effective communication, certain classifications have been designed and implemented for use. One of the generally accepted classification includes seven types of the communicative strategies, which are presented in the following part of the paper.

\section{Types of Communicative Strategies}

In all business environments, communication comes first. Every reasonable business person in the international professional community understands and values communication. However, mere understanding of its significance cannot stand for successful business and closed business deals. This is where communication strategies come handy and take the lead. Communication strategies forge and help maintain connections, communication strategies when properly applied help build up international teams and develop crossborder business effectively, communication strategies stand at attention to translate the message smoothly in order to reach the desired communicative goal.

For the purpose of the article and avoidance of tautology that a communication strategy communicates a message, we would prefer to use the term communicative strategies. Thus, below is a set of the seven most frequently used communicative strategies in the international business environment.

\section{Nomination}

Nomination refers to a communicative strategy by employing which, roughly speaking, the speaker / the sender of the information wants to open a topic with some people s/he is talking to or demonstrating an object. This strategy allows for collaboration and productivity at the same time. Next, when s/he employs nomination, the speaker / the encoder presents a particular topic in a clear, distinct and truthful way. The key aspect with nomination is to say only what is relevant. It is also important to mention that the encoder may use nomination not only for introducing an idea or object, but also in the course of their interaction. In such a circumstance, nomination deliverables are associated with the ways of continuing communication.

Thus, with nomination as a communicative strategy one may note the below criteria attributable to the interaction:

(i) Introduction of an idea, object, etc. as well as continuance of communication,

(ii) Presentation of the information in a

(C) O. I. Chaika

«International journal of philology» | «Міжнародний філологічний часопис» Vol. 11, № 1, 2020 
clear and understandable way to the recipient / decoder,

(iii) Relevance of the topic presented.

To illustrate nomination, let us look at some examples in English business environment.

$\checkmark$ CEO (Chief Executive Officer) is talking to CFO (Chief Financial Officer) and CTO (Chief Technical Officer) 'Is there anything else to add to the agenda for tomorrow?'

$\checkmark$ Chairman to the members of the Management Board, 'Have you heard the news on the merger of AgroUniversal and the Coils?'

$\checkmark$ 'That's all for the present and I'm ready for your questions if any'

$\checkmark$ 'Do you find that approach
reasonable?

\section{Restriction}

Restriction refers to a communicative strategy employed with limitations of any kind, which may arise with the speaker / sender of the information.

In some certain context, the speaker / sender of the information faces a number of constraints. Such constraints may include some of the below enlisted:

(i) Constrained response / reaction within a set of categories,

(ii) Restricted response (fully or partially) of the other communicant / the decoder involved in the communication act. The decoder, i.e. the listener / observer has to respond only within that set of categories, which is made by the encoder / the speaker.

The following situations may exemplify such communication contexts:

$\checkmark$ A lecturer addressing his / her class, 'Could you please correct the mistakes of your fellow-student and comment on errors?'

$\checkmark$ A Ukrainian businessman with poor command of general French making a business presentation in French.

\section{Turn-Taking}

Turn-taking as a communicative strategy pertains to the process by which speakers - both the encoder and the decoder, decide who takes the conversational floor. It is worth mentioning that across cultures people may keep to some accepted behaviours that may envelope into social attributes and thought patterns. However, the underlying part is to establish and move along a productive conversation and the key to success is with the idea of giving all communicators a chance to speak and share their understanding, agree or disagree on the mentioned information. Yet, it is not the only criterion to establish the strategy.

The two others inter alia are: (i) timing and ways of communication, and (ii) stepping in at the appropriate moment. The former relates to recognizing the proper moment to speak in a certain environment as well as how to speak or start speaking when their turn comes. The latter requires that everyone among the speakers encoders and decoders, respects all the communicants and attributes the encoding role, a role of the speaker, only when it is their turn in the course of interaction.

In order to follow the above, it is important to focus on various communication signs. As the introductory part of the paper specifies, the symbols can be of different nature, i.e. verbal and nonverbal. In the interaction, to make it productive and communication effective, it is the right timing, which plays the first fiddle. That means that the communicant should know when it is the appropriate time to talk, and this moment depends on watching out for some verbal and nonverbal cues that may signal the engaged communicants of their relevant turns. Thus, each communicant (to become next) may await its time and watch out diligently in order to see the developments in the communication. Such developments vary and depend on the context, for example:

- The previous speaker / encoder of the message has finished delivering the idea,

- The previous speaker / encoder of the message makes a pause and expects the audience to ask relevant questions for detail and/or to thank him / her,

- The topic under discussion exhausts

(C) O. I. Chaika

«International journal of philology» | «Міжнародний філологічний часопис» Vol. 11, № 1, 2020 
(has been exhausted),

- It is the time the other communicants introduced the new topic, etc.

Taking the above into consideration and understanding that scenarios may change to meet the context, the main thing here is that appropriate timing is crucial and it signals everyone that others have this opportunity to take their turn and speak.

To this end, turn-taking as a communicative strategy differentiates as employs two different approaches, formal and informal. The informal approach talks for itself. The speaker / the next encoder of the message acts informally, s/he just jumps in and starts talking. With the formal approach in communication and when the speaker / encoder of the message takes advantage of turn-taking, such speaker / encoder should wait for a permission to speak. S/he receives a kind of invitation to speak from the moderator in a meeting, conference, etc.

To better understand this communicative strategy, let us follow the below examples.

$\checkmark$ [Moderator in a meeting]: 'Shall we start now? And what about listening to the ideas as they are presented in the slides?

$\checkmark$ 'I'm sure we can understand the content plan well when we give each other a chance to discuss that one by one.'

$\checkmark$ 'Steven, speak on. I'll comment on your suggestions after you finish the report.'

\section{Topic control.}

Topic control is another communicative strategy employed to cover the ways of procedural formality and informality influencing the development of the topic once the speaker / encoder of the message introduces it and takes further into a conversation. As the matter concerns it is important to develop the topic collectively once it is initiated. This helps the communicants to avoid interruptions and untimely questions as well as topic shifts.

Topic control rests on the question and answer formula that helps to move the discussion forward and keeps the interaction live and ongoing by means of asking questions and listening to replies. Altogether, the strategy enables the communicants to take turns, share their ideas or argue points, and develop the discussion.

The examples of topic control may amount to a wide range of situations.

$\checkmark$ 'One of the ideas we are designing today is on introduction of the regular teambuilding within the corporation.'

$\checkmark$ 'At first, we will look at the changes in the tax legislation. Then, we will proceed with the adoption of the novices by firms and companies. Finally, we will have to decide on how to carry out the business model in our case.'

\section{Topic Shifting}

Topic shifting is another communicative strategy that involves a change in the topic, i.e. gradual or unexpected movement from one topic to another. The strategy anticipates two stages from the start. Stage 1 foresees the end of one topic in a conversation or part of the conversation. Stage 2 envelopes and sub-breaks into one of the below:

- Introduction of the new topic, to be followed by its continuation among / between the communicants, or

- Introduction of another adjacent topic.

Topic shifting as a strategy in communication works best with a followthrough. It means that it is critical for the purpose of strategy employment that the newly introduced topic develops into further discussion. There are a lot of introductory phrases and parentheses, which open the message, among the other signs in the beginning, middle or end of the message. Please see some in the below examples.

$\checkmark$ 'By the way, when is the conference on International Mergers \& Acquisitions in San Francisco?'

$\checkmark$ 'Have you also heard of their disposal of Cisco\& Co?'

$\checkmark$ 'In addition to what President said it is important we stay focused on sales performance anyway.'

\section{Repair}

Repair is a communicative strategy that

(C) O. I. Chaika

«International journal of philology» | «Міжнародний філологічний часопис» Vol. 11, № 1, 2020 
refers to how the speaker / the encoder of the message addresses some difficulties or lack of experience in speaking, listening, and understanding the message, which the speaker / encoder / decoder may encounter in a conversation. Repair aims to overcome interaction breakdown in order to send more understandable messages that the recipient / the decoder may find easier to decode and translate. In English, there are certain thought patterns and grammar clichés that may allow for repair. For instance:

$\checkmark$ 'Excuse me, the phone number is three, five, four, double four, double nine, not double five."

$\checkmark$ 'I'm sorry but his name J-O-R-G-E is spelt with a $J$ instead of a $G$ and an $E$.'

\section{Termination}

Termination as a communicative strategy anticipates closing a conversation, winding up a conversation. Thus, termination can be described via the following means attributable to this communicative strategy:

(i) Close-initiating phrases, expressions, set clusters that end the topic in a conversation,

(ii) Use of verbal and non-verbal signs to mean the end of interaction,

(iii) Verbal and non-verbal messages (a) that end communication [and] (b) sent by the speaker / encoder of the message and the listener / decoder of the message to each other.

Termination varies in the context. It may be quick and short or it may last longer to make room for clarifications, further

\section{References}

1. Chaika, Oksana (2015). Identity in Cross-linguistic Legal Context // Proceedings of the MtS conference (University of Prešov).

2. Dragojevic, Marko; Gasiorek, Jessica; Giles, Howard (2015). "Communication Accommodation Theory". The International Encyclopedia of Interpersonal Communication. pp. 1-21.

3. Giles, H., \& Ogay, T. (2007). Communication Accommodation Theory. In B. B. Whaley \& W. Samter (Eds.), Explaining communication: Contemporary theories and questions and answers. Sometimes the topic may continue into further discussion, however, the language including body language speaks of approaching the end and this is a point in interaction just about to end communication. Let us see termination in the examples and the ways of how the strategy develops in the relevant context.

$\checkmark$ 'Remember me to your Managing Partner and tell him I'll be in London the next week.'

$\checkmark$ 'It has been a great conference, a good number of smart ideas and business solutions. It was nice to meet you again. Take a safe trip back home.'

$\checkmark$ 'The class is over and everyone has an individual home assignment. Good-bye and see you all on Monday!

Conclusion. The work presented has explored the relevance of intercultural communication in the English-speaking business environment with a precise focus on a restricted set of the seven communicative strategies described. Each strategy contains its definition and a number of criteria to follow it. At the same time, the English contextual examples enrich the explanations and demonstrate the importance of cross-cultural messaging at the relevant stages, i.e. encoding of a message, choice of the medium/media to deliver the information, and decoding of a message. Further research will be dedicated to communicative strategies and foreign language instruction / acquisition.

exemplars (pp. 293-310). Mahwah, NJ: Lawrence Erlbaum.

4. Goddard, Cliff, Wierzbicka, Anna (2018) Minimal English for a Global World, pp.5-27. DOI: 10.1007/978-3-319-62512$6 \_2$

5. Lauring, Jakob (2011). "Intercultural Organizational Communication: The Social Organizing of Interaction in International Encounters". Journal of Business Communication. 48 (3): 231-5.

6. Saint-Jacques, Bernard (2011). "Intercultural Communication in a Globalized 
World." In Intercultural Communication: A Reader, edited by Larry A. Samovar, Richard E. Porter, and Edwin R. McDaniel, 13 edition, 45-53. Boston, Mass: Cengage Learning.

7. Su Kei, Shum (2015). "The Significance of Intercultural Communication for Businesses and the Obstacles that Managers should Overcome in Achieving Effective Intercultural Communication".
8. Tiszczenko, Oleg (2011) Etnicita Slovanského areálu (Historické proměny a současný stav) [Text] / ed.: Mgr. Kateřina Kedron, Ph. D. (jazykovědna č.), PhDr. Marek Přihoda, Ph. D. (literárněvědná a hist. č.). Červený Kostelec : [Pavel Mervart] ; Praha : [Filoz. fak. Univ. Karlovy v Praze], 2011. 252 s. : sl., tab. - (Russia Altera ; sv. 19. řada Slavica. sv. 9). - ISBN 978-80-87378-83-0.

\section{КОМУНІКАТИВНІ СТРАТЕГІЇ У МІЖКУЛЬТУРНОМУ БІЗНЕС-ПРОСТОРІ О. І. Чайка}

Анотація. У статті йдеться про роль і вагомість міжкультурної комунікації в англомовній бізнес-спільноті з практичним фоккусом і готовим рішенням для ділового світу. Це - набір комунікативних стратегій, які можуть застосовувати в міжнародному бізнесі як ділові люди, так $і$ аудитори й бухгалтери зокрема. Актуальність проблематики визначає низку задач. Для досягнення мети подається: а) загальний опис поняття міжкультурної комунікації; б) етапи передачі інфоормаційних повідомлень - кодування повідомлення, вибір засобу/ів для передачі відповідного повідомлення та декодування повідомлення; в) класифрікація комунікативних стратегій за типами офоомлення контекстуального змісту. Наприкінці результати дослідження підкреслюють необхідність уніфрікованого підходу до спрощених моделей міжкультурної комунікації, незалежно від географрічного й часового континуумів, а також спонукають до використання описаних комунікативних стратегій, що можуть стати у нагоді для ефрективної комунікації у бізнес-середовищі.

Ключові слова: міжкультурна комунікація, кодування / декодування повідомлення, вибір носія для передачі інформації, комунікативна стратегія. 